\title{
Farmers' Perceptions of Maize Production Systems and Breeding Priorities, and Their Implications for the Adoption of New Varieties in Selected Areas of the Highland Agro-Ecology of Ethiopia
}

\author{
Demissew Abakemal ${ }^{1,2}$, Shimelis Hussein ${ }^{1}$, John Derera ${ }^{1} \&$ Mark Laing $^{1}$ \\ ${ }^{1}$ African Center for Crop Improvement, University of KwaZulu-Natal, Private Bag X01, Scottsxille 3209, \\ Pietermaritzburg, South Africa \\ ${ }^{2}$ Ethiopian Institute of Agricultural Research, Ambo-PPRC, Ethiopia, P.O.Box 37, Ambo, Ethiopia \\ Correspondence: Demissew Abakemal, African Center for Crop Improvement, University of KwaZulu-Natal, \\ Private Bag X01, Scottsxille 3209, Pietermaritzburg, South Africa. E-mail: dakemal@yahoo.com
}

\author{
Received: October 25, 2012 Accepted: March 4, 2013 Online Published: October 15, 2013 \\ doi:10.5539/jas.v5n11p159 URL: http://dx.doi.org/10.5539/jas.v5n11p159
}

\begin{abstract}
Maize (Zea mays L.) plays a critical role in smallholder food security in Ethiopia. Its production is rapidly increasing to the Highlands of Ethiopia where it has been a minor crop in the past. This study aimed to assess the magnitude and production systems of Highland maize, farmers' production constraints, and their implications for the adoption of new maize cultivars in two zones of the Oromia Regional State representing the Highland sub-humid agro-ecology of Ethiopia. A participatory rural appraisal (PRA) was conducted with eight peasant associations involving 160 experienced maize farmers from four districts during 2012. Primary data were collected through Focused Group Discussions (FGDs) and Semi-structured Interviews (SSI). Farmers' maize cultivar preferences showed that few adopted Highland cultivars are available. Instead a two-decade old cultivar, 'BH660', originally released for the mid-altitude agro-ecology, has been widely adopted in most Highland areas. As regards cultivars' trait preferences, non-significant variation $(\mathrm{P}>0.05)$ was observed among farmers between the two study zones. Farmers (both men and women) in the study areas unanimously considered grain yield as the most important trait for maize cultivar selection. Major production constraints were also identified and listed by farmers, of which limited access to inputs (improved maize seeds and inorganic fertilizers), and late on-set and inadequate rainfall were the primary constraints across the study areas.
\end{abstract}

Keywords: Ethiopia, focused group discussion, highland maize, participatory rural appraisal, maize traits, PRA

\section{Introduction}

Agriculture is the mainstay of Ethiopia's economy. The majority of farmers operate mainly on small farms, in rain-fed cropping systems and livestock production. Small-scale farming predominately produces limited food to support the small-holder farmers and their family for consumption, leaving little to sell. Consequently, improving agricultural productivity is a national priority in Ethiopia. According to the Central Statistical Agency of Ethiopia (CSA, 2010), the low level of crop productivity in the country is attributed to inefficient farming methods that utilize outdated crop production and protection technologies, and fragmented pieces of land holdings . To bridge the gap between the demand and supply for food, and also to enhance the desired change in the livelihood of majority of the population, the government of Ethiopia launched a five year Growth and Transformation Plan (GTP). The plan includes transformation of the agricultural sector towards surplus-producing, market-oriented smallholder agriculture capable of achieving accelerated and sustainable economic development in the country (The Federal Democratic Republic of Ethiopia [FDRE], 2011).

The need for food security and the diverse agro-climatic conditions in Ethiopia have prompted the majority of subsistence farmers to grow various crops. One major shift is that over the past 20 years, the area dedicated to maize cultivation in Ethiopia has expanded progressively. Of the major cereal crops, maize ranks second to tef [Eragrostis tef(Zucc.)] in area and first in production (Mosisa et al., 2002, 2012). Over the last 20 years, the area under maize has increased by about $50 \%$ and production by $66 \%$, with the national average yield of maize increasing from 1.6 to $3.0 \mathrm{t} \mathrm{ha}^{-1}$ (CSA, 2011). The per capita consumption of maize is $60 \mathrm{~kg}_{\text {year }}^{-1}$ per annum in 
Ethiopia (Mosisa et al., 2012). Maize is therefore a crucial for Ethiopia in the short and medium term, and the GTP proposes a maize doubling of production by 2015 (FDRE, 2011).

Although a substantial quantity of maize is produced in the lowland areas, most maize is grown in the most productive agricultural lands in the mid and highland areas of the country. The crop is increasingly grown to the Highlands of Ethiopia where it has been a minor crop in the past. The high altitude, sub-humid maize agro-ecology (1800-2400 m.a.s.l.) in Ethiopia is estimated to cover $20 \%$ of the land devoted to annual maize cultivation. More than $30 \%$ of small-scale farmers in this agro-ecology depend on maize production for their livelihoods (Twumasi et al., 2002). To meet the needs of increasing maize production in the Highlands of Ethiopia, the Ethiopian Highland Maize Breeding Program was established with the support of the International Maize and Wheat Improvement Center (CIMMYT), in 1998. The program is based at the Ambo Plant Protection Research Center of the Ethiopian Institute of Agricultural Research. It is aimed at developing and popularizing improved Highland maize cultivars, and enhancing their crop management technological packages.

From 1999 to 2011, the breeding program released five superior Highland maize hybrids including: AMB02SYN1-'Hora', AMH800-'Arganne', AMH850-'Wenchi', AMH851-'Jibat', and AMH760Q-'Webi', for large-scale production. AMH760Q was released as a quality protein maize (QPM) hybrid, which was developed from the most popular, top-yielding non-QPM hybrid 'BH660'. Over 5.8 million hectares of potential suitable land was identified for the highland maize hybrids in the country (Demeke et al., 2012). However, the hybrids have not been aggressively popularized, and have not been adopted by farmers in the Highlands. Reasons for the slow rate of adoption include: (1) lack of awareness of the released cultivars in the Highland environment, and (2) the carryover effect of lack of awareness of the cultivars has resulted in untargeted seed distribution of the previously released mid-altitude maize cultivars in the Highlands. According to Dawit et al. (2010), one of the main reasons for seed leftovers in either public or private seed stocks during high demand has been associated with the limited efficiency of targeting seed production and distribution in Ethiopia. It is also believed that some superior cultivars that have been released might not have been adopted because of lack of sufficient considerations of farmers' preferences in their development process (Banziger \& Cooper, 2001; Derera et al., 2006). Participatory rural appraisal (PRA) is a research tool to integrate farmers' perceptions, constraints and preferences into agricultural research so that improved technologies can be developed that become widely adopted (De Groote \& Bellon, 2000). The objective of the current study was, therefore, to assess the magnitude of production of maize, the systems used and the farmers' production constraints, and their implications for the adoption of new maize cultivars in two zones of the Oromia Regional State representing the Highland, sub-humid agro-ecology of Ethiopia.

\section{Methodology}

\subsection{Study Area Description}

A participatory rural appraisal study was conducted in 2012 in two administrative zones, i.e., West Shoa and East Arsi of the Oromia Regional State of Ethiopia. The zones were selected based on their experience of growing Highland maize cultivars and local varieties. There are 18 and 24 districts in the West Shoa and East Arsi zones, respectively. The districts are situated near the Highland maize research centres because of the extension and popularization work done by the research centres in these districts. Previously released Highland maize cultivars widely grow in these districts. Further, the areas represent a High altitude, sub-humid agro-ecology with altitudinal ranges between 2000 and 2400 mean above sea level. The study zones are known for their agricultural potential particularly the rain-fed production of small grain cereals (wheat, tef, barley). In these zones, maize is largely grown as a rain-fed crop, although a few farmers in West Shoa also produce maize using local irrigation schemes during the off-season. In most years, both zones receive enough rainfall for crop production in the main season. The 'Meher' season, which encompasses June to October, is the main cropping and rainy season for both zones. Five major cereal crops, namely tef (Eragrostis tef Zucc.), maize (Zea mays L.), sorghum (Sorghum bicolour L.), wheat (Triticum aestivum L.) and barley (Hordeum vulgare L.) are grown in the West Shoa and East Arsi zones. In the West Shoa zone, maize ranks second to tef in cultivation area, while it ranks fourth after wheat, barley, and tef in the East Arsi zone, which is a wheat belt of Ethiopia.

\subsection{Sampling Procedures}

A multi-stage sampling was carried out whereby two districts (administrative units below the zonal level) in each administrative zone were selected. Ambo and Toke-Kutayei districts represented the West Shoa zone, and Tiyo and Hitosa, the East Arsi zone. From each district, two sub-districts or peasant associations (PAs) were further selected making the total number of eight PAs (Table 1). Furthermore, 20 farmers from each PA were interviewed, providing a total of 160 farmers for the study. The selections from the zonal through the districts, 
PAs and farmers levels were based on the criterion of a long production background of the farmers in Highland maize production. Individual farmers were selected from each PA representing various socio-economic backgrounds (data not shown) and both genders. Thus the farmers selected for this micro-study were representative of the highland maize farmers in the two zones.

\subsection{Data Collection and Analyses}

All primary data were collected through the PRA process. The secondary data was obtained from the Central Statistical Agency of Ethiopia (www.csa.gov.et). Local extension staff and sub-district managers at the respective localities facilitated the PRA process by mobilizing farmers to participate on the Focused Group Discussions (FGDs). FGDs, accompanied by semi-structured interviews (SSI), were held in January-February. Zones are intermediate administrative categories found above district and below regional levels.

Table 1. The selected study areas in West Shoa and East Arsi zones of the Oromia Regional State in Ethiopia

\begin{tabular}{llllll}
\hline Zones & Districts & Sub-districts & $\begin{array}{l}\text { Altitude } \\
(\mathrm{m})\end{array}$ & \multicolumn{2}{l}{ No. of farmers } \\
\cline { 5 - 6 } & & (PAs) & & Women & Men \\
\hline \multirow{3}{*}{ West Shoa } & \multirow{2}{*}{ Ambo } & Gosu Kora & 2350 & 3 & 17 \\
& & Boji Gebisa & 2250 & 2 & 18 \\
& \multirow{2}{*}{ Toke-Kutayei } & Kolba-Lencha & 2350 & 2 & 18 \\
& & Birbirsa-Dogoma & 2200 & 3 & 17 \\
\hline \multirow{3}{*}{ East } & \multirow{2}{*}{ Tiyo } & Gora silingo & 2300 & 4 & 16 \\
& & Oda dewata & 2280 & 9 & 11 \\
& \multirow{2}{*}{ Hitosa } & Sheki Sherera & 2250 & - & 20 \\
& & Oda Jila & 2300 & 2 & 18 \\
\hline
\end{tabular}

$\mathrm{PA}=$ peasant association.

2012 at eight sites, one per sub-districts. Each FGD and SSI meeting was held outdoors and started with a minimum of 15 participants who varied in gender and age (data not shown). In the course of the process, the number increased to 20 participants. The farmers sat together and discussed maize farming issues that were common and general in nature. They were also interviewed individually to explore more specific issues and particularly to deal with issues that were traditionally sensitive to the farmers. Both the FGDs and individual farmers' interviews were held in local language, "Afan Oromo", using semi-structured questionnaires designed to collect data, as well as to guide the discussions, yet to allow the participants' freedom to raise relevant issues of their own. The FGDs focused mainly on the following four themes: farm characteristics which highlighted the importance of maize for Highland farmers, farmers' preferences for named maize cultivars, traits of interest in maize cultivars and the perceived constraints affecting maize production.

The FGDs with farmers included questions involving the main cropping season, the major crops grown, the benefits of maze for Highland farmers, and ranking of the major crops based on estimated farm operations, which later involved matrix ranking following Ceccarelli's (2012) procedure. Further, farmers were asked to list their main criteria for maize cultivar selection, ranking the criteria, and to identify the preferred traits found in the maize varieties they had been growing. The scale used for the assessment of the selection criteria was: $1=$ poor, 2 = fairly good, $3=$ good, $4=$ very good, 5 = best and $6=$ excellent. An independent sample t-test was run to test equality of means of ranks obtained from the eight PAs of the two zones for each preferred trait. Using grain yield as the criterion set by farmers, the maize cultivars known to farmers and those commonly grown in the study areas were also listed and ranked one up to six depending on the number of cultivars and score interval at the specific locations- one being the worse, three for good, and six for excellent. The FGDs also helped to identify and prioritize production constraints for Highland maize.

Household interviews included questions such as the area of land cultivated by each farmer, and the proportion of land devoted to maize cultivation. Descriptive statistics were applied to the data, together with a Pearson correlation analysis to test for an association between the area of land cultivated and the proportion devoted to maize production. Farmers' awareness of quality protein maize (QPM) and their interest in QPM were emphasized during the FGD. Accordingly, attitudes towards QPM were determined from each respondent farmer 
using a 4-point scale where $1=$ 'strong acceptance', 2 = 'acceptance', 3 = 'neutral', and $4=$ 'negative'. These attitudinal data were subjected to a statistical test for independency in a $4 \mathrm{x} 4$ contingency table. SPSS (version 19) computer software (SPSS, 1989-2010) was used to perform statistical analyses for this study.

\section{Results}

\subsection{Farm Characteristics and Maize Production Systems}

\subsubsection{Importance of Growing Maize}

In all the study areas land has been used for growing crops, livestock grazing, human settlement and afforestation (data not shown). As expected, the 'Meher' season was the only major maize growing season. During this season, famers grow other major cereal crops including wheat, tef, barley, sorghum as well as pulse and oil crops. During group discussions, farmers expressed their views that the experience of maize farming as a homestead crop in all the study areas dated back to more than half a century. However, it was only a few decades since maize became a major field crop in the Highland environment.

Farmers listed six primary reasons for increasing maize production in their area. Firstly, due to its high productivity relative to other cereal. Secondly, maize is versatile as a food. Thirdly, surplus maize is also a cash crop which can be sold to generate household income either as green cobs or as grain after satisfying the households' food requirements. Fourthly, maize is used for livestock feed using maize stover. Fifthly, it is used in crop rotation systems with small cereals such as wheat and barley. Sixthly, it provides an edible crop earlier than barley and wheat, filling a critical "hunger" period.

\subsubsection{Area under Maize Production}

In the study areas most farmers allocated a substantial portion of their lands for maize production (Figure 1). For instance, a relatively larger area $(0.75 \mathrm{ha})$ was allocated to maize by several subsistence farmers in the three PAs in the West Shoa zone. Maximum values of up to 1.5 ha were also recorded for a few farmers in one of the PAs ('Birbirsa-Dogoma') in the West Shoa zone, where $75 \%$ of the respondent farmers grow maize on $>0.5$ ha of land. On the other hand, a maximum land allocation of 0.5 ha was recorded for most of the PAs in the East Arsi zone, although one farmer allocated 0.75 ha to maize. Minimum areas under maize cultivation ranged from 0.125 to 0.25 ha, and 0.1 ha were also recorded for the PAs in the West Shoa and East Arsi PRA zones, respectively.

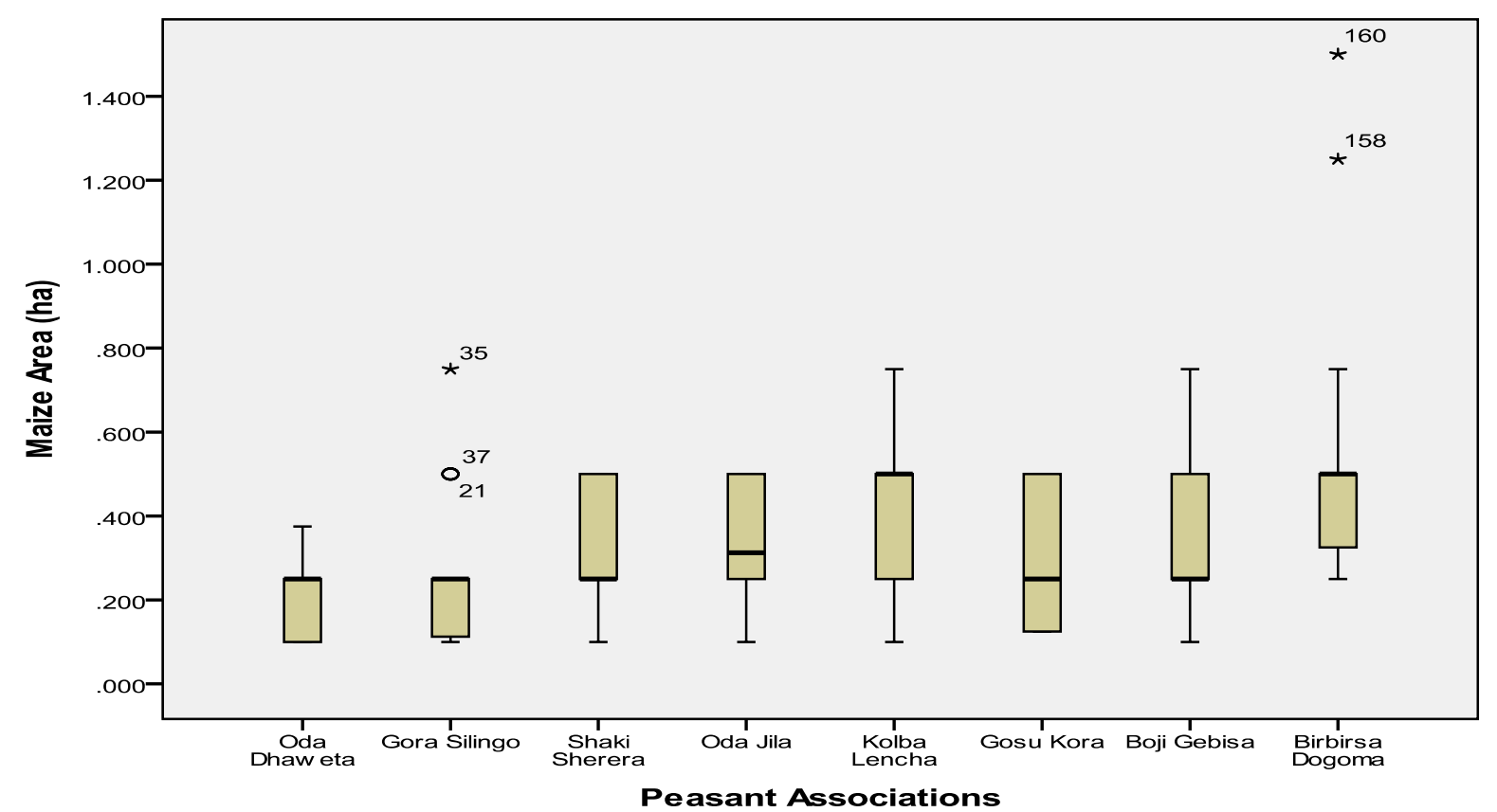

Figure 1. Mean area (ha) allocated to maize production among eight peasant associations in two administrative Zones of the Oromia regional state of Ethiopia 
An associational study between the area of land owned by farmers and the area allocated to maize suggested a highly significant and positive correlation $(r=0.41, P<0.01)$ (Figure 2). In general, as the size of the total land holding (farm) increased, the size of land allocated for maize production also increased. However, there were incidences of exceptional farmers who allocated less land for maize production. Considering the 80 farmers in each PRA zone, the average total land owned by individual farmers (or mean farm size) was: 1.7 ha (Oda Dewata), 2.4 ha (Gora Silingo), 2.6 ha (Sheki Sherera), 3.4 ha (Oda Jila), 3.8 ha (Kolba-Lencha), 3.9 ha (Gosu Kora), 3.6 ha (Boji-Gebisa), and 2.5 ha (Birbirsa-Dogoma). Similarly, the corresponding mean maize production area on each farm was: 0.19 ha (Oda Dewata), 0.24 ha (Gora Silingo), 0.30 ha (Sheki Sherera), 0.34 ha (Oda Jila), 0.41 ha (Kolba-Lencha), 0.30 ha (Gosu Kora), 0.38 ha (Boji-Gebisa), and 0.53 ha (Birbirsa-Dogoma). Hence, more land was allocated to maize in the West Shoa zone than the East Arsi zone.

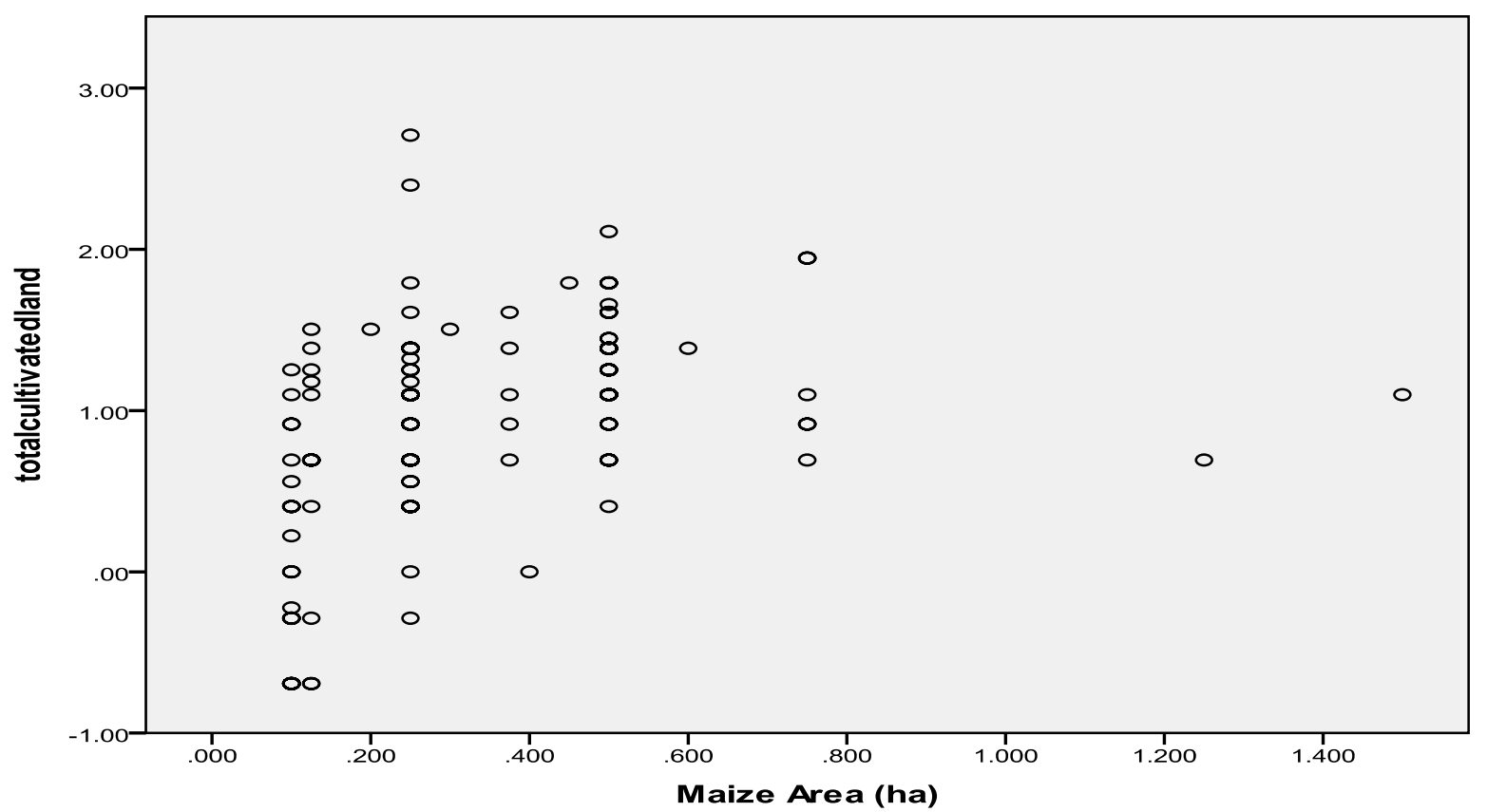

Figure 2. Association between the total cultivated land and area allocated to maize production

\subsubsection{Farming Activities}

Farmers in the study areas were also asked to rank the primary farm operations for the major cereal crops grown. This was done based on their estimation of costs involved per activity by crops (Table 2). A matrix ranking approach was used which showed that maize ranked on the top in terms of cost estimations for two out of the five farm operation, namely planting, and weeding and/or cultivation. Farmers explained that the cost of these operations was highest for "improved" varieties of maize. Seeds of improved maize varieties are manually planted in rows and then require 2-3 rounds of fertilizer application and cultivation for weed control. The farmers needed to hire labour, or to request assistance from neighbouring households, during critical periods of the cropping season. Because of this, some of the farmers explained that they usually prefer to plant their own local varieties which demand less crop management practices, and thus lower production costs and labour demands.

During group discussions, women farmers were requested to provide their crop preferences for use as food. All the groups in all areas unanimously chose maize. Women confirmed that maize could be consumed three times a day by the households' family either as green cob or as a processed product mixed with other cereal crops such as wheat and tef. However, the groups also noted that maize could not be consumed alone because of its low nutritive value and fast digestibility that result in hunger soon after feeding. The farmers' groups added two more reasons why they used maize as a staple crop: Firstly, because it matures early, maize plays a critical role in providing food to farmers and their families during a three month "hunger period" when the other cereal crops (wheat, tef and barley) are maturing and cannot be consumed. This is also the time when grain reserves from the 
previous season have started to run out; Secondly, the other cereal crops such as tef and wheat fetch better prices than maize in these areas, which persuades farmers keep the maize for home consumptions, and to sell the other cereals.

Table 2. Ranking of the cost of farm operations for cereal crops

\begin{tabular}{|c|c|c|c|c|c|c|c|c|}
\hline \multirow[t]{2}{*}{ Farm operations } & \multirow[t]{2}{*}{ Crops } & \multicolumn{5}{|c|}{$\begin{array}{l}\text { Individual rank based on cost } \\
\text { estimations* }\end{array}$} & \multirow{2}{*}{$\begin{array}{l}\text { Rank } \\
\text { index }\end{array}$} & \multirow{2}{*}{$\begin{array}{c}\text { Overall } \\
\text { rank }\end{array}$} \\
\hline & & 1 & 2 & 3 & 4 & 5 & & \\
\hline \multirow{5}{*}{ Land preparation } & Maize & 35 & 20 & 70 & 5 & 30 & 455 & 3 \\
\hline & Wheat & 15 & 5 & 20 & 80 & 40 & 605 & 2 \\
\hline & Tef & 15 & 10 & 20 & 45 & 70 & 625 & 1 \\
\hline & Barley & 40 & 75 & 20 & 10 & 15 & 365 & 4 \\
\hline & Sorghum & 55 & 50 & 30 & 20 & 5 & 350 & 5 \\
\hline \multirow{5}{*}{ Purchase of seed } & Maize & 45 & 70 & 20 & 10 & 15 & 360 & 4 \\
\hline & Wheat & 20 & 10 & 15 & 43 & 72 & 617 & 1 \\
\hline & Tef & 10 & 5 & 25 & 82 & 38 & 613 & 2 \\
\hline & Barley & 35 & 20 & 65 & 10 & 30 & 460 & 3 \\
\hline & Sorghum & 50 & 55 & 35 & 15 & 5 & 350 & 5 \\
\hline \multirow{5}{*}{ Planting } & Maize & 10 & 7 & 15 & 50 & 78 & 659 & 1 \\
\hline & Wheat & 35 & 20 & 70 & 5 & 30 & 455 & 3 \\
\hline & Tef & 20 & 8 & 25 & 75 & 32 & 571 & 2 \\
\hline & Barley & 40 & 70 & 20 & 15 & 15 & 375 & 4 \\
\hline & Sorghum & 55 & 55 & 30 & 15 & 5 & 340 & 5 \\
\hline \multirow{5}{*}{ Weeding and cultivation } & Maize & 10 & 10 & 25 & 35 & 80 & 645 & 1 \\
\hline & Wheat & 50 & 62 & 25 & 15 & 8 & 349 & 4 \\
\hline & Tef & 15 & 5 & 20 & 90 & 30 & 595 & 2 \\
\hline & Barley & 50 & 63 & 25 & 15 & 7 & 346 & 5 \\
\hline & Sorghum & 35 & 20 & 65 & 5 & 35 & 465 & 3 \\
\hline \multirow{5}{*}{$\begin{array}{l}\text { Harvesting and } \\
\text { transportation }\end{array}$} & Maize & 47 & 61 & 30 & 13 & 9 & 356 & 4 \\
\hline & Wheat & 6 & 9 & 25 & 86 & 34 & 613 & 2 \\
\hline & Tef & 20 & 12 & 13 & 39 & 76 & 619 & 1 \\
\hline & Barley & 37 & 18 & 63 & 10 & 32 & 462 & 3 \\
\hline & Sorghum & 50 & 60 & 29 & 12 & 9 & 350 & 5 \\
\hline
\end{tabular}

Notes: Rank index $=$ Summations of rank $\times$ number (Ceccarelli, 2012); $*$ Where $1=$ low cost, $3=$ intermediate, and $5=$ high cost based on the farm operation under question.

\subsection{Maize Cultivar Preferences and Farmers-Preferred Traits}

\subsubsection{Types of Cultivars}

Table 3 shows the maize cultivars and local varieties that were known and listed by farmers during the group discussions. A few cultivars were known to most farmers but were grown only in small quantities in almost all the study areas, with the exceptions of one cultivar 'BH600', which was widely grown in substantial quantities. Among the varieties grown on a small area of land $(<0.25$ ha) by a limited number of farmers were the relatively recently released Highland maize cultivars such as Arganne, Wenchi, Jibat, and Hora, which were still being grown in demonstration plots. In contrast, local varieties such as 'Oromei' are widely grown by most homesteads. 
BH660 is a long season three-way hybrid developed for the mid-altitude and transitional highland agro-ecologies, with a wide adaptation spanning an altitudinal range of between 1600-2200 m.a.s.l. On the other hand, the four highland maize cultivars, Arganne, Wenchi, Jibat, and Hora, were released for transitional to true highland agro-ecologies. However, their adoption has been very limited. The first three are hybrids, while the fourth is an open pollinated variety (OPV). Kuleni and Katumani are OPVs with contrasting adaptations. The former was adapted to mid-altitude and transitional highland areas while the latter is an old variety initially introduced from Kenya for drought stressed areas in Ethiopia. From the group discussions, it was clear that Katumani was only grown to a small extent by some farmers in the East Arsi zone. Not only Katumani but also other OPVs including Hora and Kuleni had better acceptance by farmers in the East Arsi compared to the West Shoa zone where hybrids were more preferred than the OPVs.

Table 3. The maize cultivars listed and ranked by famers in the study zones based on grain yield during FGD

\begin{tabular}{|c|c|c|c|c|c|c|c|c|c|}
\hline \multirow[b]{2}{*}{ Zones } & \multirow{2}{*}{$\begin{array}{l}\text { Peasant } \\
\text { Associations }\end{array}$} & \multicolumn{8}{|c|}{ Cultivars and year of release } \\
\hline & & $\begin{array}{l}\text { BH660 } \\
\text { (1993) }\end{array}$ & $\begin{array}{l}\text { Arganne } \\
(2005)\end{array}$ & $\begin{array}{l}\text { Wenchi } \\
\text { (2007) }\end{array}$ & $\begin{array}{l}\text { Jibat } \\
(2009\end{array}$ & $\begin{array}{l}\text { Hora } \\
(2005)\end{array}$ & $\begin{array}{l}\text { Kuleni } \\
\text { (1995) }\end{array}$ & Katumani & Local* \\
\hline \multirow{4}{*}{ East Arsi } & Gora Silingo & 6 & 4 & - & - & 5 & 3 & 2 & 1 \\
\hline & Oda Dewata & 4 & - & - & - & 3 & - & 2 & 1 \\
\hline & Sheki Sherera & 6 & 4 & $\sqrt{ }$ & $\sqrt{ }$ & 5 & 3 & 2 & 1 \\
\hline & Oda Jila & $\sqrt{ }$ & 4 & $\sqrt{ }$ & - & 3 & 2 & - & 1 \\
\hline \multirow{4}{*}{ West Shoa } & Gosu Kora & 6 & 3 & 5 & 4 & 2 & - & - & 1 \\
\hline & Boji Gebisa & 5 & 4 & 2 & $\sqrt{ }$ & 3 & - & - & 1 \\
\hline & Kolba-Lencha & 4 & 2 & 3 & $\sqrt{ }$ & - & - & - & 1 \\
\hline & Birbirsa-Dogoma & 5 & 2 & 4 & - & 3 & - & - & 1 \\
\hline
\end{tabular}

$*=$ different types of varieties; $\sqrt{ }=$ the cultivar was known by a few farmers; $1=$ worse, $2=$ fairly good, $3=$ good, $4=$ very good, $5=$ best, and $6=$ excellent.

In all the study areas, farmers indicated that they had used several local varieties for more than half a century (Table 3). The source of these varieties was unknown but they had been grown in small areas around homesteads where the soil fertility was reasonably good and farmers do not need to apply inorganic fertilizers. Farmers do not apply inorganic fertilizers to local varieties because (1) these varieties are considered potentially low yielders and consequently farmers do not want to incur fertilizer costs; and (2) the farmers believed that their local varieties would start to "want" fertilizer like the improved varieties that were developed by research centres under conditions of high fertility.

Table 4. The most important traits of maize varieties, as ranked by farmers in both PRA zones

\begin{tabular}{lcccc}
\hline Best criterion & East Arsi Zone & West Shoa Zone & Overall & Sig.(2-tailed t-test) \\
\hline Yield & 5.75 & 6.00 & 5.88 & 0.356 \\
Maturity & 4.50 & 5.00 & 4.75 & 0.134 \\
Plant height & 4.50 & 4.00 & 4.25 & 0.134 \\
Storability & 1.50 & 1.25 & 1.38 & 0.537 \\
Marketability & 2.50 & 3.00 & 2.75 & 0.356 \\
Feed & 1.50 & 1.75 & 1.62 & 0.537 \\
\hline
\end{tabular}

Ranking: 1 represented the least preferred and 6 the most preferred trait. 


\subsubsection{Trait Preferences}

The mean rankings of farmers-preferred traits for maize cultivars are presented in Table 4. A non-significant difference $(\mathrm{P}>0.05)$ was observed between farmers in ranking their preferences of cultivars' trait in the study zones. High yield was the most important criterion used in selection of cultivars in the study areas. Most of farmers (98\%) in all PAs, except Sheki Sherera and Gora Silingo, identified the maturity period of cultivars as the second most important after yield, while plant height was ranked second to yield by $70 \%$ of the farmers in two PAs, Sheki Sherera and Gora Silingo (data not shown). Farmers of these two PAs strongly preferred intermediate plant height after yield and explained that short statured cultivars were more prone to attacks by either wild or stray domestic or wild animals such as dogs and porcupines than an intermediate or a tall variety.

Conversely, tallness was not desirable because of the associated problem of lodging. On the other hand, most farmers who preferred early maturity as the second most important trait explained that they usually practice a relay cropping system whereby pulse crops, such as chickpea (Cicer arietinum L.) and grass pea (Lathyrus sativus L.), would be sown immediately after physiological maturity of maize and before the land dried out completely. Earliness is a relative term because the farmers preferred intermediate season cultivars to very short season cultivars. Almost all farmers in the study areas, however, do not want extra-early maturing cultivar because such a cultivar might be the first to mature in an area and therefore might suffer from exceptional animals' and bird damage.

Marketability ranked fourth among farmer-preferred traits. During group discussions, farmers explained that a cultivar whose grains have a glossy (flint-textured) characteristics and hard endosperm types command better acceptability in local markets than dent-textured and chalky types, when sold as both green and grain maize. Farmers' also considered local varieties to provide superior quality in the preparation of traditional beverages. But in terms of all other characters listed in Table 4, local varieties were considered inferior to the improved cultivars. In general, farmers in all PRA areas were not concerned much about storability and feed quality in maize and ranked them low. Farmers argued that they had not seen a maize cultivar with resistance to storage pests, nor with special qualities as feed for animals.

\subsection{Major Production Constraints}

The focused groups at each study area described important constraints to maize production. The groups also identified and listed the major constraints recognized and agreed on by most participants in the two study zones (Table 5). The constraints were listed in five categories, including pre-planting and planting of maize, vegetative growth, harvesting and consumption, and marketing. Farmers were then guided to prioritize the constraints under each category in each PA which, in turn, helped to establish the single most important constraint from each of the five categories so as to make pair-wise comparisons among the selected constraints independently for each PA. Overall, there were coincidences of similarity between PAs in their prioritization of constraints. PAs having similar priorities and rankings in their pair-wise comparisons were merged and presented in pairs in Table 6.

The two most important production constraints were late and inadequate rainfall, and limited access to improved maize cultivars in all the study areas.

Table 5. Maize production constraints identified and listed under five categories by farmers during FGD in the study areas

\begin{tabular}{|c|c|c|c|c|c|}
\hline Constraints & Pre-planting to planting & $\begin{array}{l}\text { Seedling to } \\
\text { harvesting }\end{array}$ & Post-harvest & Consumption & Marketing \\
\hline \multirow{5}{*}{ 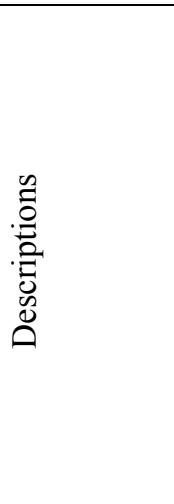 } & Late onset of rain & Stalk borer & Weevils & $\begin{array}{l}\text { Poor nutritional } \\
\text { value }\end{array}$ & $\begin{array}{l}\text { Low maize } \\
\text { price }\end{array}$ \\
\hline & Shortage of rain & $\begin{array}{l}\text { Shortage of } \\
\text { rain }\end{array}$ & Termites & $\begin{array}{l}\text { Poor baking } \\
\text { quality }\end{array}$ & $\begin{array}{l}\text { Instability of } \\
\text { maize price }\end{array}$ \\
\hline & $\begin{array}{l}\text { Limited access to improved } \\
\text { seed \& high cost of inorganic } \\
\text { fertilizers }\end{array}$ & $\begin{array}{l}\text { Weak } \\
\text { extension } \\
\text { services } \\
\text { Wild and } \\
\text { domestic } \\
\text { animals }\end{array}$ & Rodents & & \\
\hline & $\begin{array}{l}\text { Untimely distribution of } \\
\text { inputs }\end{array}$ & & & & \\
\hline & Weak extension services & & & & \\
\hline
\end{tabular}


Table 6. Pair-wise comparisons of five major constraints identified and prioritized by farmers in the eight PAs

\begin{tabular}{|c|c|c|c|c|c|c|c|c|}
\hline PAs & Constraints & 1 & 2 & 3 & 4 & 5 & $\begin{array}{l}\text { Total } \\
\text { score }\end{array}$ & Rank \\
\hline \multirow{6}{*}{ Gosu Kora } & 1. Late on-set and shortage of rain & * & 1 & 1 & 1 & 1 & 4 & 1 \\
\hline & 2. Stalk borer & & $*$ & 3 & 2 & 5 & 1 & 4 \\
\hline & 3. Weevils & & & $*$ & 3 & 5 & 2 & 3 \\
\hline & 4. Poor baking quality & & & & $*$ & 5 & 0 & 5 \\
\hline & 5. Low price of maize & & & & & $*$ & 3 & 2 \\
\hline & Total & & & & & & 10 & \\
\hline \multirow{5}{*}{ Oda Dewata } & 1. Late on-set and shortage of rain & * & 2 & 1 & 1 & & 2 & 2 \\
\hline & 2. Stalk borer & & $*$ & 2 & 2 & & 3 & 1 \\
\hline & 3. Weevils & & & * & 3 & & 1 & 3 \\
\hline & 4. Low price of maize & & & & $*$ & & 0 & 4 \\
\hline & Total & & & & & & 6 & \\
\hline \multirow{6}{*}{$\begin{array}{l}\text { Kolba-Lencha and Sheki } \\
\text { Sherera }\end{array}$} & 1. Limited access to improved seeds & * & 1 & 1 & 1 & 1 & 4 & 1 \\
\hline & 2. Shortage of rain & & $*$ & 2 & 2 & 2 & 3 & 2 \\
\hline & 3. Weevils & & & * & 3 & 3 & 2 & 3 \\
\hline & 4. Poor nutritive value & & & & $*$ & 5 & 0 & 5 \\
\hline & 5. Low price of maize & & & & & $*$ & 1 & 4 \\
\hline & Total & & & & & & 10 & \\
\hline \multirow{6}{*}{$\begin{array}{l}\text { Gora Silingo and Oda } \\
\text { Jila }\end{array}$} & 1. $\quad$ Limited access to improved seeds & * & 1 & 1 & 1 & 1 & 4 & 1 \\
\hline & 2. Stalk borer & & $*$ & 2 & 2 & 2 & 3 & 2 \\
\hline & 3. Weevils & & & * & 3 & 3 & 2 & 3 \\
\hline & 4. Poor baking quality & & & & $*$ & 4 & 1 & 4 \\
\hline & 5. Low price of maize & & & & & $*$ & 0 & 5 \\
\hline & Total & & & & & & 10 & \\
\hline \multirow{6}{*}{$\begin{array}{l}\text { Birbirsa-Dogoma } \\
\text { Boji Gebisa }\end{array}$} & 1. Shortage of rain & $*$ & 1 & 1 & 1 & 1 & 4 & 1 \\
\hline & 2. Limited access to improved seeds & & $*$ & 2 & 2 & 2 & 3 & 2 \\
\hline & 3. Weevils & & & $*$ & 3 & 5 & 1 & 4 \\
\hline & 4. Poor nutritive value & & & & $*$ & 5 & 0 & 5 \\
\hline & 5. Low price of maize & & & & & $*$ & 2 & 3 \\
\hline & Total & & & & & & 10 & \\
\hline
\end{tabular}

Where, rank 1 stands for high priority and 5 for the least.

\subsubsection{Inadequate Rainfall}

Farmers in all but two of the PAs (Gora Silingo and Oda Jila) explained that inadequate rainfall is a challenge to maize production in their area. In some cropping seasons farmers were forced not to plant maize and they panted the land prepared for maize with other small grain cereal crops. The consequence of not planting maize for a season usually led to hunger in their families especially in the months of July to September when no grain reserves remained.

\subsubsection{Inefficient Input Distribution}

All but two of the PAs (Gosu Kora and Oda Dewata) mentioned that poor seed distribution of improved cultivars, both temporal and spatial, by the extension system, cooperatives and unions was a major problem. There was also no alternative commercial seed available on the formal market. This situation was further 
exacerbated by the untargeted and limited capacity nationally for seed production and distribution that focused on few maize cultivars, both by the public and private seed sectors. Farmers further clarified that seed distributions through the extension system have usually been effected very late in the cropping season after the rains had started and land preparations accomplished.

The same problem existed for fertilizer distribution. The price of inorganic fertilizers was a further issue and the key fertilizers were priced beyond their means, and their return from the maize they produced. On the other hand, when farmers responded to the question as to why should they use inorganic fertilizer if they could not afford the costs; they said that their farm lands have already been adapted to inorganic fertilizers and thus it would be unthinkable to grow improved cultivars without inorganic fertilizers. Although organic fertilizers such as compost and manure could, in theory, replace inorganic fertilizers, their reality was that the bulk required per unit area, and limited availability to farmers limited their large scale application, and dependency on inorganic fertilizers.

\subsubsection{Low Maize Price}

As summarized in Table 6, the low price of maize was the third most important constraint to farmers in Birbirsa-Dogoma, Boji Gebisa, and Gosu Kora PAs. The three PAs that ranked the low price of maize at the third level were the PAs in which the extent of maize production was relatively high in terms of area coverage. However, individual farmers of these PAs had decided not to increase the magnitude of their present production levels, given that the prevailing price of maize. This was unattractive for several reasons, including imbalance between supply and demand of maize, and lack of a year-round market. In seasons of bumper maize production, supply exceeded demand, which resulted in maize being left to rot both in the field and storage.

\subsubsection{Biotic Constraints}

Post-harvest loss due to weevils was perceived as the third most important constraint to Kolba-Lencha, Sheki Sherera, Oda Dewata, Gora Silingo, and Oda Jila farmers. Out of these five PAs, the former (Kolba-Lencha) was from West Shoa and the latter four were from the East Arsi zone, suggesting the universal importance of this constraint in both zones. In contrast stalk borer is a localized problem. It was recorded as the most important problem ahead of all other constraints in Oda Dewata, and as the second most important constraint in Gora Silingo and Oda Jila, but it was not even mentioned as problem in the other PAs.

\subsubsection{Poor Nutrition and Processing Quality}

Finally, the two quality constraints (poor nutritive value and baking quality) were ranked as the least important constraints. Farmers described the poor baking quality of maize in relation to the level of elasticity observed for one of the traditional and favourite food "Injera", which is often made from maize flour. The "Injera" from maize is often crumbly after baking. To improve such character, farmers usually mix grains of maize with tef in varied proportions before milling. Tef is an indigenous and popular crop in Ethiopia well known for making good quality "Injera".

With respect to the poor nutritive value of maize, farmers associated this with the rapid digestibility of maize, which would subsequently predispose the household's family, especially of children, to hunger immediately after feeding on maize or maize products. Farmers further commented that there was no any weight gain by children being fed maize foods only. The farmers' solution to this problem was to mix maize with other cereal grains such as wheat or tef in the preparation of staple food. However, when QPM (nutritionally enhanced maize) was put forward for discussion as a superior option against malnutrition the farmers were very eager to grow such varieties, provided that they would get comparable yields from the QPM varieties. Table 7 reveals farmers' opinion towards QPM in the different study areas. The degree of acceptance of QPM was not the same across the four districts of the two PRA zones as determined by the significant chi-square test $(P<0.01$, Pearson chi-square value $=30.022$ ). Strong acceptance for QPM was exhibited by more district in West Shoa than in East Arsi, where neutral opinions were expressed. This suggested the need for an educational program to create awareness about QPM in the farm households at large, to reduce the number of households with either neutral or negative opinions on QPM. 
Table 7. Association between degree of acceptance to QPM and the four districts in two zones of the Oromia regional state of Ethiopia

\begin{tabular}{lccccc}
\hline \multirow{2}{*}{ Districts } & \multicolumn{5}{c}{ Degree of acceptance* } \\
\cline { 2 - 6 } & strong acceptance & acceptance & neutral & negative \\
\hline Tiyo & 6 & 11 & 15 & 8 & 40 \\
Hetosa & 7 & 14 & 17 & 2 & 40 \\
Toke-Kutaye & 21 & 12 & 5 & 2 & 40 \\
Ambo & 16 & 11 & 6 & 7 & 40 \\
\hline Total & 50 & 48 & 43 & 19 & 160 \\
\cline { 2 - 5 } is statistically significant at the $P<0.01$ and degrees of freedom $(\mathrm{df})=9$.
\end{tabular}

\section{Discussion}

In the past, small cereal crops such as tef, wheat and barley were the most widely grown food crops in the Highlands of Ethiopia, especially in the West Shoa and East Arsi zones, where maize used to be considered a homestead crop of minor importance. To date maize has become the most important cereal crop of the Highland farmers in Ethiopia. The major reasons have been described earlier. Furthermore, the price of maize and other food crops become high during the planting season of the small grains, and before their harvest (July-October) in Ethiopia. . This is the time when farmers and their families suffer from a serious shortage of food. Consequently, the green maize is a vital crop that helps to supply early season food. In another PRA study conducted in the Dendi district of the West Shoa zone, it was also revealed that there has been a crop change over the last ten years, whereby maize had been replacing major crops such as wheat and barley (Land Use Planning and Resource Management Project in Oromia Region, Unpublished work 1999).

Although maize is being rapidly adopted in the Highland agro-ecology, the few highland cultivars that have been released have not been adopted by most highland farmers. Instead the mid-altitude hybrid cultivar 'BH660' has been widely adopted in most Highland areas. Even in case of seed shortages or the absence of this cultivar, farmers prefer to plant either the recycled seeds of the same hybrid, or their own local varieties. This has been a common phenomenon with many new crop varieties' failure before meeting their targets that they are intended for. For example, McGuire (2008) reported that despite 25 years of sorghum breeding in Ethiopia, most of the released cultivars had been poorly adopted by small-scale farmers. The failure of adoption occurs as a result of plant breeders try to identify the key problem and provide solutions without talking with the farming communities they serve (Girma et al., 2005). In addition, most research-extension-farmer linkages in Ethiopia followed a top-down approach in the past (Alene et al., 2000).

Many maize cultivars have been released in Ethiopia without including inputs from the farmers in the process of developing of the cultivars. This has been accomplished in such a way that agricultural research centres routinely assemble breeding nurseries and form experimental varieties to be tested under regional and national performance trials with the objective of generating desirable agronomic data to identify the best cross combinations or varieties for release (Mosisa et al., 2002). The problem of such highly controlled breeding and varietal selection processes is that they usually do not represent farmers' circumstances (such as low fertility, acid soil). Secondly, the limited number of traits considered by breeders as important traits in a cultivar may not represent farmers' preferences. A study by De Groote et al. (2002) was also in agreement with this idea in that poor correlations were observed between farmers' and breeders' evaluations of maize varieties using the Mother-Baby methodology of participatory breeding. Many studies, however, support the idea that including farmers in problem identification and solution search may facilitate success in adoption of new technologies.

Although farmers' trait preferences are diverse and complex (Witcombe \& Virk, 1997), the farmers in this study described and prioritized the most important traits they use for maize cultivar selection. It was observed that there was no statistically significant difference regarding farmers' trait preferences between the two PRA zones, suggesting that these two zones could be included under same recommendation domain when new maize cultivar development and deployment are sought. It was interesting to note that farmers in all the study areas were in agreement that grain yield of maize is the most important trait compared to all other traits, including enhanced nutrition in maize (e.g. QPM). This is the reason that a two-decades-old and yet top yielding maize hybrid 'BH660', despite its lateness in maturity and tall plant height, dominates the seed sale in major maize producing 
areas of Ethiopia to date. Girma et al. (2005) found that farmers in moisture stress areas were willing to adopt drought tolerant maize varieties since they were confident of their high yield and earliness. A similar PRA conducted in Zimbabwe also found that high yield of maize was the most important criterion in variety selection by farmers (Derera et al., 2006).

Yield potential of maize can be enhanced through agronomic interventions such as improved seeds, chemical fertilizers, integrated pest management, crop rotation, irrigation, and improved technical efficiency. However, the maize production system in the two PRA zones has been challenged by a number of constraints across the value chain that limit the productivity and income of smallholder farmers. According to the International Food Policy Research Institute (IFPRI, 2010), in Ethiopia, maize producers are mostly subsistence farmers, both in terms of numbers and in terms of total product volume. They are characterized by ownership of small fields (usually less than 2 hectares, as witnessed in this study) and low utilization of yield enhancing technologies such as hybrid seeds and inorganic fertilizers. Moreover, maize farmers sell the majority of their produce immediately after harvest when the price is lowest, because of urgent cash needs (including loan repayments) and fear of losses to storage pests due to unimproved storage structures. Hence, a balance between farmers-preferred traits and solutions to production constraints should be the breeders' goal in order to enhance cultivar dissemination and uptake by farmers (Hussein \& Laing, 2012). This can be achieved through the implementation of participatory plant breeding approaches that involve a wide number of relevant stakeholders in the system.

\section{Conclusion and Recommendations}

From the trend in maize production over the past five years, as reflected in this study, it is possible to forecast increasing demand for maize in the Highland agro-ecology of Ethiopia. Maize will grow as a component of household food security. Therefore, in the context of developing the maize production system toward improving the food, nutrition and income security of subsistence farmers in Ethiopia in general, and in the two PRA zones in particular, it is important to envision a comprehensive intervention approach that embraces the entire value chain. This will involve key stakeholders during the processes of improvements in variety development, adoption, production, aggregation and marketing. Being able to create such an effective chain will help to fast track holistic improvements in supply, demand and market mechanisms.

Regarding improvements in varietal development, the overall issues that need to be addressed by the Highland maize breeders include developing a suitable maize cultivar which incorporate the trait preferences of farmers such as high yield, intermediate plant statures and maturity periods, flint textured grains, field and storage pest resistance/tolerance, and enhanced nutritional and baking quality. While incorporating all or some of these traits into new cultivars, breeders should make sure that there is no yield penalty in these cultivars since this is an essential trait for farmers in the study areas.

As to the non-breeding interventions, many farmers in the study areas reported that improved seeds and fertilizer were either not available, or that their delivery was too late. Where they were available, they were unaffordable. Therefore, institutional directions to facilitate the adoption of new maize cultivars should focus on reducing input costs by making sustainable improvements in infrastructure, transportation, credit availability, and markets. The results of this study also identified the need for extension services in awareness creation among farmers about new Highland maize cultivars and how to manage them best.

\section{Acknowledgements}

We are grateful to farmers of the study zones who made this participatory rural appraisal study possible. The Bureau of Agriculture staff at zone and district levels, development agents, and the Ambo Plant Protection Research centre are greatly acknowledged for facilitation of the work. Thanks also go to the Alliance for a Green Revolution in Africa for funding this research.

\section{References}

Alene, A. D., Poonyth, D., \& Hassan, R. M. (2000). Determinants of adoption and intensity of use of improved maize varieties in the central highlands of Ethiopia: A tobit analysis. Agrekon, 39, 633-643. http://dx.doi.org/10.1080/03031853.2000.9523679

Banziger, M., \& Cooper, M. (2001). Breeding for low input conditions and consequences for participatory plant breeding: examples from tropical maize and wheat. Euphytica, 122, 503-519. http://dx.doi.org/10.1023/A:1017510928038

Ceccarelli, S. (2012). Plant breeding with farmers - a technical manual. Aleppo, Syria: ICARDA. 
CSA. (2010). Agricultural Sample Survey 2010/2011:Report on area and production of major crops (private peasant holdings, 'Meher' season). Statistical Bulletin. Vol. 1. Addis Ababa, Ethiopia: The Central Statistical Agency of Ethiopia (CSA).

CSA. (2011). Agricultural Sample Survey 2011/2012: Report on area and production of major crops (private peasant holdings, 'Meher' season). Statistical Bulletin. Vol. 1. Addis Ababa: CSA.

Dawit, A., Shahid, S., \& Tripp, R. (2010). Seed system potential in Ethiopia: Constraints and opportunities for enhancing the seed sector. Washington DC: International Food Policy Research Institute.

De Groote, H., \& Bellon, M. (2000). Farmers' participatory research: Application for breeders. Paper presented at a workshop "PRA for IRMA" held at Kenyan Agricultural Research Institute Headquarters, 9-11 November 2000 Nairobi, Kenya. Nairobi: CIMMYT and KARI.

De Groote, H., Siambi, M., Friesen, D., \& Diallo, A. (2002). Identifying farmers' preferences for new maize varieties in Eastern Africa. In M. R. Bellon, \& J. Reeves (Eds.), Quantitative analysis of data from participatory methods in plant breeding. Mexico DF: CIMMYT.

Demeke, N., Dawit, A., \& Degefie, T. (2012). Agro-ecological suitability for hybrid maize varieties and its implication for seed systems. In S.T. Afriyie et al. (Eds.), Meeting the Challenges of Global Climate Change and Food Security through Innovative Maize Research. Proceedings of the Third National Maize Workshop of Ethiopia, 16-20 April 2012 Addis Ababa, Ethiopia. Addis Ababa: EIAR (Ethiopian Institute of Agricultural Research) and CIMMYT.

Derera, J., Tongoona, P., Langyintuo, A., Laing, M. D., \& Vivek, B. S. (2006). Farmer perceptions on maize cultivars in the marginal Eastern belt of Zimbabwe and their implications for breeding. African Crop Science Journal, 14, 1-15.

FDRE. (2011). The Federal Democratic Republic of Ethiopia (FDRE), Five Year Plan for Growth and Transformation (2011-2015). Addis Ababa, Ethiopia: Ministry of Finance and Economic Development.

Girma, A., Teshale, A., Hussen, H., Tewodrose, M., \& Abdel-Rahman, M. T. (2005). Participatory selection of drought tolerant maize varieties using mother and baby methodology: A case study in the semi-Arid zones of the central rift valley of Ethiopia. World Journal of Agricultural Sciences, 1, 22-27.

Hussein, S., \& Laing, M. D. (2012). Timelines in conventional crop improvement: pre-breeding and breeding procedures. Australian Journal of Crop Science, 6, 1542-1549.

IFPRI. (2010). Maize value chain potential in Ethiopia: Constraints and opportunities for enhancing the system. Working Paper. Washington DC: IFPRI (International Food Policy Research Institute).

McGuire, S. J. (2008). Path-dependency in plant breeding: challenges facing participatory reform in the Ethiopian $\begin{array}{llll}\text { sorghum improvement program. Agricultural Systems, } & \text { 96, 139-149. }\end{array}$ http://dx.doi.org/10.1016/j.agsy.2007.07.003

Mosisa, W., Abdurahaman, J., Tulu, L., Tuna, H., Wolde, L., Yihun, K., ... Zeleke, H. (2002). Improved germplasm development for the mid and low altitude sub-humid agro-ecologies of Ethiopia. In M. Nigusse, \& D. Tanner (Eds.), Proceedings of the Second National Maize Workshop of Ethiopia, 12-16 November 2001 Addis Ababa, Ethiopia (pp. 27-30). Addis Ababa: EARO (Ethiopian Agricultural Research Organization) and CIMMYT.

Mosisa, W., Legesse, W., Berhanu, T., Girma, D., Girum, A., Wende, A., ... Getachew, B. (2012). Status and future direction of maize research and production in Ethiopia. In W. Mosisa et al. (Eds.), Proceedings of the Third National Maize Workshop of Ethiopia, 16-20 April 2012 Addis Ababa, Ethiopia (pp. 17-23). Addis Ababa: EIAR and CIMMYT.

SPSS (Statistical Product and Service Solutions). (1989-2010). SPSS for Windows Release 14.0. SPSS Inc. 1989-2010. IBM Company.

Twumasi-Afriyie, S., Zelleke, H., Yihun, K., Assefa, B., \& Tariku, S. (2002). Development and Improvement of Highland Maize in Ethiopia. In M. Nigusse, \& D. Tanner (Eds.), Proceedings of the Second National Maize Workshop of Ethiopia, 12-16 November 2001 Addis Ababa, Ethiopia (pp. 31-38). Addis Ababa: EARO and CIMMYT.

Witcombe, J. R., \& Virk, D. S. (1997). New directions in public sector variety testing. In R. Tripp (Ed.), New seeds and old laws: regulatory reforms and the diversification of national seed system (pp. 59-87). London: Intermediate Technology Publications. 


\section{Copyrights}

Copyright for this article is retained by the author(s), with first publication rights granted to the journal.

This is an open-access article distributed under the terms and conditions of the Creative Commons Attribution license (http://creativecommons.org/licenses/by/3.0/). 